\title{
An Analysis of Wildlife Roadkill Based on Land Cover in South Korea Expressway: In Case of Jungbu Expressway
}

\author{
JiYoung Choi ${ }^{1}$, Hyo Min Park ${ }^{1}$ and Sang Don Lee ${ }^{1}$ \\ ${ }^{1}$ Department of Environmental Science and Engineering, College of Engineering, Ewha Womans University, \\ Seoul 120-750, Korea
}

\begin{abstract}
This study analyzed land type of the hotspot section of roadkill with roadkill data and adjacent land cover data in Jungbu expressway using a GIS analysis during 2009-2013.

Roadkill species status was that Korean water deer(Hydropotes inermis) was totaled in 207 individuals(51.88\%) with the highest figure, Korean raccoon dog(Nyctereutes procyonoides) was 16(41.03\%), Wild Boar(Sus scrofa) was 2(20\%), Small-eared cat(Prionailurus bengalensis) was 1(16.67\%), Korean hare(Lepus coreanus) was 1(25\%), Korean badger(Meles meles) was 1(50\%), Korean roe deer(Capreolus Capreolus) was 2(100\%). Seasonal status was to analyze through a monthly analysis. Most roadkill is the highest in spring and summer. This indicated that the range of activities is related to characteristics of dispersion behavior before the autumn and winter. Land use type of roadkill hotspot were forest area, agricultural area, grass land these are appropriate habitat for animals, the ratio of roadkill is considered to be higher than in other regions. Total area of land use at roadkill points is evidently growing in 2013 compared to the ones in 2012. Thus it is very important to continuously analyze land use type at roadkill hotspots to minimize and mitigate the impact of roadkill on wildlife.

This study implied that the relationship between land use and roadkill frequent areas knowing the main species of roadkill. This can be used as the basis data that expressway route selection for the roadkill mitigation in the future and the locating consideration for the artificial construction such as green bridge, eco-corridor for the current expressway.
\end{abstract}

Keywords: Roadkill, Land use type, GIS, Expressway, South Korea.

\section{Introduction}

Construction of expressway can interfere with the movement of wildlife due to destruction of habitat. It causes destruction in ecosystem such as wildlife populations decline, biodiversity degradation [1]. Also unlike the common road, the expressway has generated a large fragmentation through the forest to straighten the express line, it influences between species and species in the future and affects the movement of habitat fragmentation and distribution of the species [2]. In addition, increasing vehicle transportation along with the road construction reduces the habitat of a vertebrate generating the visual field defect and traffic noise [3].

Previous roadkill studies have focused on negative impact of roads on the ecosystem [4], [5]. Also, a wide range of studies to reduce roadkill have been implemented in other counties. In particular, the studies on the characteristics of the section in which the roadkill occur frequently have been conducted. However, these research findings are difficult to apply to South Korea due to the difference of species, surrounding environment and road construction. Therefore this study analyzed land type of the hotspot section of roadkill with roadkill data and adjacent land cover data in Jungbu expressway using a GIS analysis.

\section{Materials and methods}

\section{Study Area}

This study was conducted on Jungbu Expressway passing through Mooju-gun and Jangsu-gun in Jeonllabukdo, Hamyang-gun in Gyeongsangnam-do (Fig.1). Considerations were made: 1) the line which has cumulatively frequent roadkill, 2) the line affecting habitat fragmentation due to expressway construction in Deogyusan and Jirisan National Park of South Korea. 

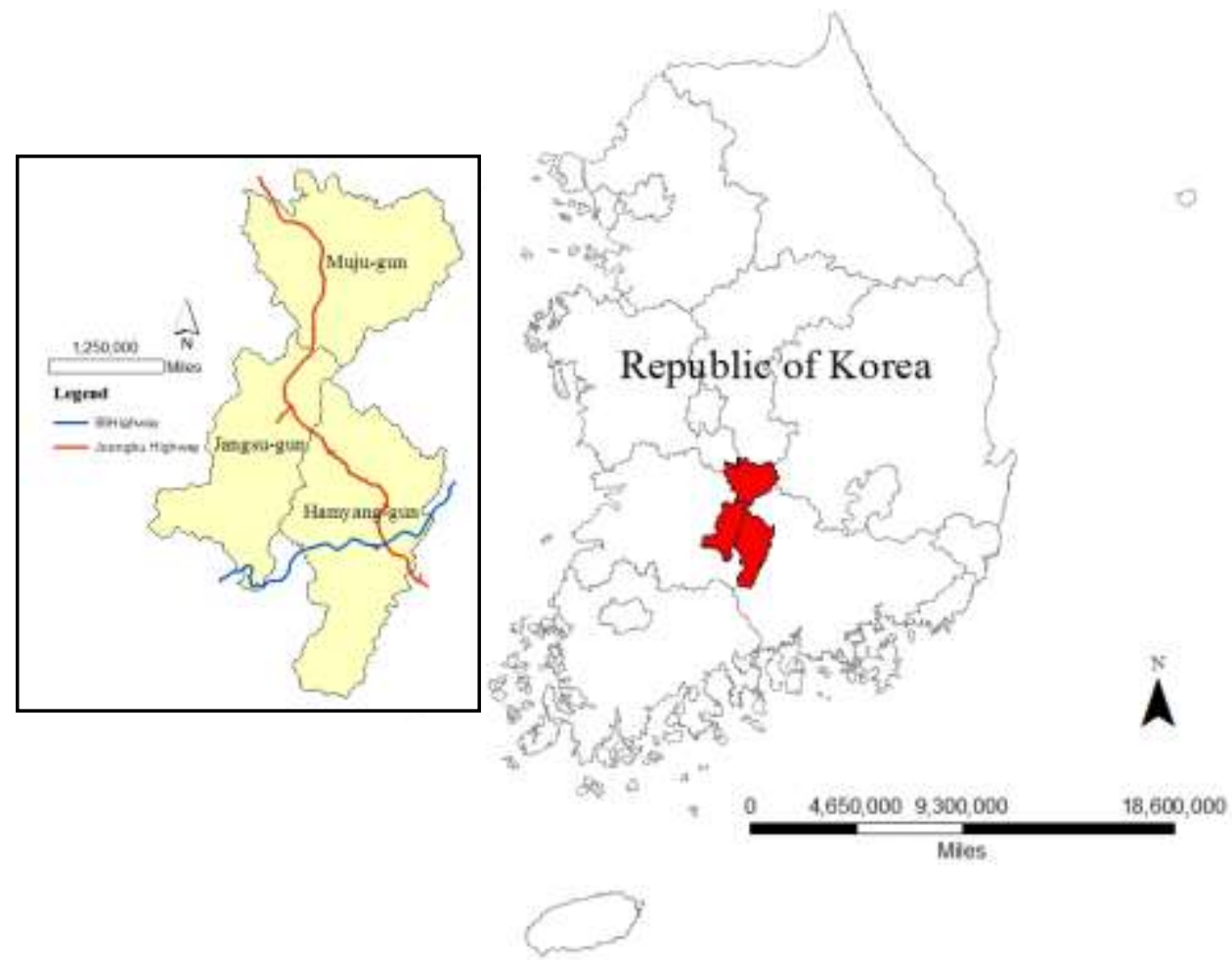

Fig. 1: Map Showing Muju-Hamyang IC in Jungbu expressway

\section{Materials and Methods}

Roadkill surveys have been conducted daily by Korea Expressway Corporation and they have recorded the location, species and date. We used the roadkill data which were collected during 2009-2013. Data were collected on eight mammals: Korean water deer (Hydropotes inermis), Korean raccoon dog (Nyctereutes procyonoides), Korean roe deer (Capreolus Capreolus), Korean hare (Lepus coreanus), Small-eared cat (Prionailurus bengalensis), Korean badger (Meles meles), Wild Boar (Sus scrofa) and Otter (Lutra lutra).

We conducted the roadkill analysis by species and season. Seasonal status was identified through a monthly analysis. It was divided into Spring (Mar.-May.), Summer (Jun.-Aug.), Autumn (Sep.-Nov.) and Winter (Dec.Feb.). And we also built a spatial database using the roadkill data and adjacent land cover map in 2012-2013. GIS analysis was constructed with Arc GIS 9.3.1 and Arcview GIS Ver.3.3 [6]. Because our purpose is to understand the land type of the roadkill hotspot section, we build a series of buffer area (width 50m) along the hotspot section and analyzed the land use types within the radius of $50 \mathrm{~m}$ range at each point of roadkill.

\section{Results and Discussion}

\subsection{Roadkill status by species}

The cumulative number of roadkills in Jungbu expressway was aggregated into a total of 463. In Jungbu expressway, $60.4 \mathrm{~km}$ of Muju-Hamyang IC (49.68\%) is one of the most frequent occurrence section of roadkill. At this Muju-Hamyang IC section of the Jungbu expressway, Korean water deer (H. inermis) was totaled in 207 individuals $(51.88 \%)$ with the highest value; Korean raccoon dog (N. procyonoides) was 16 (41.03\%), Wild Boar (S. scrofa) was 2 (20\%), Small-eared cat (P. bengalensis) was 1 (16.67\%), Korean hare (L. coreanus) was 1 (25\%), Korean badger (M. meles) was 1 (50\%), Korean roe deer (C. Capreolus) was 2 (100\%), Otter (L. lutra) was $0(0 \%)$ (TABLE I). The number of the Korean water deer and Korean raccoon dog is accounted for the highest percentage in the 223 individuals. Due to their behavioral characteristics of Korean water deer and 
Korean raccoon dog, roadkill is mostly likely to have occurred at night [7]. Because Korean raccoon dogs have less fear and hostility toward artificial facilities such as road, their mortality rate seem to be high [8].

TABLE I: Number of roadkill and the roadkill percentage (\%) occurred at Muju-Hamyang IC section of the Jungbu expressway during 2009-2013

\begin{tabular}{|c|c|c|c|}
\hline \multirow{2}{*}{ Species/Number of roadkill } & $\begin{array}{c}\text { Jungbu } \\
\text { expressway }\end{array}$ & Muju-Hamyang IC & \multirow{2}{*}{ Percentage $(\%)$} \\
\hline & $(165.6 \mathrm{~km})$ & $(60.4 \mathrm{~km})$ & \\
\hline $\begin{array}{c}\text { Korean water deer } \\
\text { (Hydropotes inermis) }\end{array}$ & 399 & 207 & 51.88 \\
\hline $\begin{array}{l}\text { Korean raccoon dog } \\
\text { (Nyctereutes procyonoides) }\end{array}$ & 39 & 16 & 41.03 \\
\hline $\begin{array}{l}\text { Wild Boar } \\
\text { (Sus scrofa) }\end{array}$ & 10 & 2 & 20 \\
\hline $\begin{array}{c}\text { Small-eared cat } \\
\text { (Prionailurus bengalensis) }\end{array}$ & 6 & 1 & 16.67 \\
\hline $\begin{array}{c}\text { Korean hare } \\
\text { (Lepus coreanus })\end{array}$ & 4 & 1 & 25 \\
\hline $\begin{array}{l}\text { Korean badger } \\
\text { (Meles meles) }\end{array}$ & 2 & 1 & 50 \\
\hline $\begin{array}{c}\text { Korean roe deer } \\
\text { (Capreolus Capreolus) }\end{array}$ & 2 & 2 & 100 \\
\hline $\begin{array}{c}\text { Otter } \\
\text { (Lutra lutra) }\end{array}$ & 1 & 0 & 0 \\
\hline Total & 463 & 230 & 49.68 \\
\hline
\end{tabular}

\subsection{Roadkill status by season}

A number of roadkills were higher in spring and summer than in autumn and winter(Fig. 2). In case of Korean water deer, they mainly mate in December-January and produce 3 4 cub in June after having a gestation period of about 210 days. Therefore, more frequent traffic accidents are to be occurred during this period because of their physiological characteristics [8]. The result is phenomenon in the behavior of the movement of breeding animals in the spring [8]. In addition, Korean raccoon dogs do not hibernate during the winter and they often cross the road to hunt the prey in the winter. This is one of the reasons that are causing the raccoon dog's roadkill continuously in the winter as well as in spring.

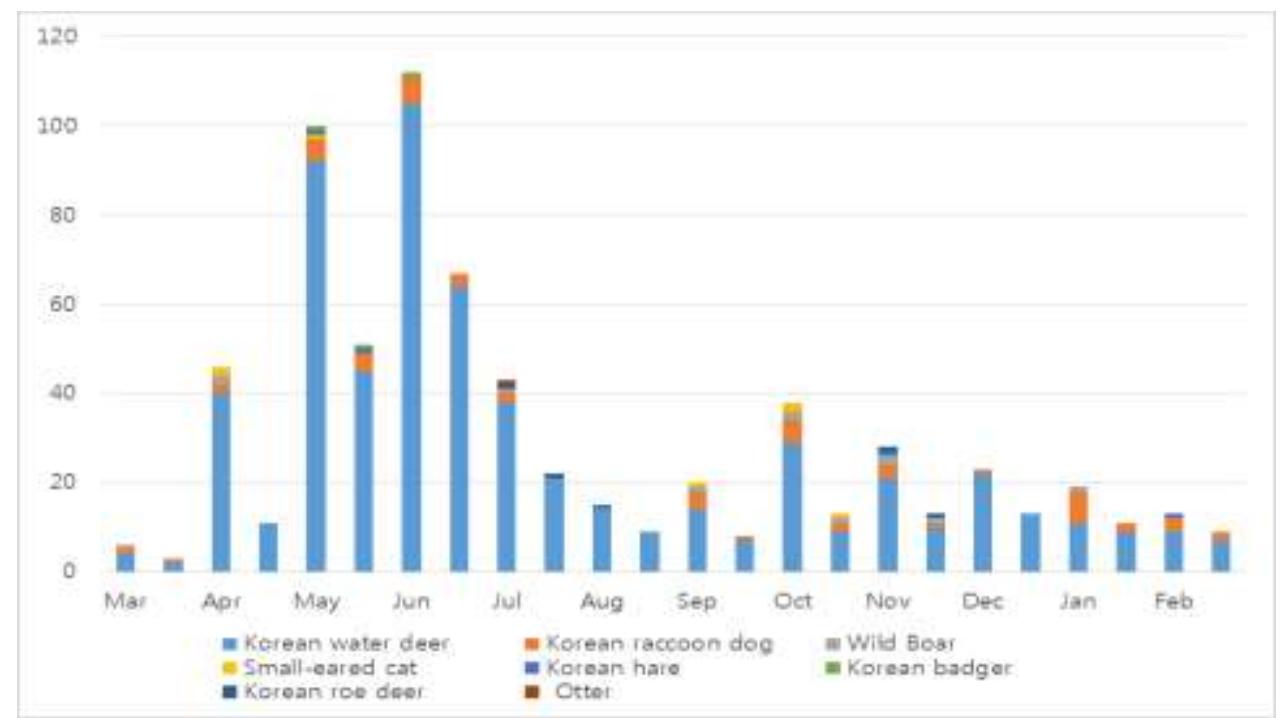

Fig. 2: Roadkill occurrence by month during 2009-2013(First: Jungbu expressway, Second: Muju-Hamyang IC) 


\subsection{Land use type and value at roadkill hotspot}

To understand the land type of the hotspot section for roadkill, we build a buffer area (width 50m) along the hotspot section. As a result, forest area was $62.59 \%$, the largest proportion followed by Agricultural area (22.81\%), Glass land (6.94\%), Bare land (3.70\%), Urban area (2.14\%), Waters (1.79\%) and Wetland $(0.02 \%)$ (TABLE II). We analyzed land use type by overlapping buffers created with a radius of 50m at roadkill occurrence point. As a result, forest area was $58.71 \%$, the largest proportion followed by Agricultural area (26.34\%), Glass land (6.33\%), Bare land (4.24\%), Urban area (4.21\%) and Waters $(0.17 \%)$ in 2012(TABLE III). And in 2013, forest area was 54.39\%, the largest proportion followed by Agricultural area (25.98\%), Glass land (11.24\%), Urban area (4.40\%), Bare land (3.85\%), and Waters (0.14\%) (TABLE IV). As a result of the analysis of land use types, most of the study area consist of forest area, agricultural area and glass land.The land use type of roadkill hotspot was forest area, agricultural area and glass land. The ratio of roadkill is considered to be higher in these regions than in others becuase forest area, agricultural area and glass land are appropriate habitat for animals. Total area of land use at roadkill points is evidently growing in 2013 compared to the ones in 2012. Thus it is very important to continuously analyze land use type at loadkill hotspots to minimize and mitigate the impact of roadkill on wildlife.

TABLE II: Land use value of Muju-Hamyang IC section (50m buffer)

\begin{tabular}{ccc}
\hline \hline Land use type & Area $\left(\mathrm{km}^{2}\right)$ & $\%$ \\
\hline Urban area & 0.201 & 2.14 \\
Agricultural area & 2.141 & 22.81 \\
Forest & 5.875 & 62.59 \\
Glass land & 0.652 & 6.94 \\
Wet land & 0.002 & 0.02 \\
Bare land & 0.348 & 3.70 \\
Waters & 0.168 & 1.79 \\
Total & $\mathbf{9 . 3 8 7}$ & $\mathbf{1 0 0}$ \\
\hline \hline
\end{tabular}

TABLE III: Land use value at point of roadkill occurred in Muju-Hamyang IC section in 2012

\begin{tabular}{ccc}
\hline \hline Land use type & Area $\left(\mathrm{km}^{2}\right)$ & \% \\
\hline Urban area & 0.019 & 4.21 \\
Agricultural area & 0.121 & 26.34 \\
Forest & 0.271 & 58.71 \\
Glass land & 0.029 & 6.33 \\
Wet land & - & - \\
Bare land & 0.020 & 4.24 \\
Waters & 0.001 & 0.17 \\
\hline Total & $\mathbf{0 . 4 6 1}$ & $\mathbf{1 0 0}$ \\
\hline \hline
\end{tabular}


TABLE IV: Land use value at point of roadkill occurred in Muju-Hamyang IC section in 2013

\begin{tabular}{ccc}
\hline \hline Land use type & Area $\left(\mathrm{km}^{2}\right)$ & \% \\
\hline Urban area & 0.025 & 4.40 \\
Agricultural area & 0.146 & 25.98 \\
Forest & 0.306 & 54.39 \\
Glass land & 0.063 & 11.24 \\
Wet land & - & - \\
Bare land & 0.022 & 3.85 \\
Waters & 0.001 & 0.14 \\
\hline Total & $\mathbf{0 . 5 6 3}$ & $\mathbf{1 0 0}$ \\
\hline \hline
\end{tabular}

\section{Acknowledgements}

The research was supported by the Korea Expressway Corporation. Thanked for the given the basic data. The authors wish to thank NRF (2009-0083527) and KEITI (2014000130010) for financial support.

\section{References}

[1] G. Kim and J. Choi, "A Theoretical Study on the Wildlife Passage for Connecting Fragmented Habitat," Journal of the Korean Institute of Landscape Architecture, 26: 293-307, 1998.

[2] Brotons and L. Herrando, "Reduced bird occurrence in pine forest fragments associated with read proximity in a Mediterranean agricultural area," Landscape and Urban Planning, 57: 77-89, 2001.

http://dx.doi.org/10.1016/S0169-2046(01)00191-8

[3] R. Forman and L. E Alexander, "Roads and their major ecological effects," Annual Review of Ecology and Systematics, 29: 207-231, 1998.

http://dx.doi.org/10.1146/annurev.ecolsys.29.1.207

[4] KE. Gunson, G. Mountrakis, and L. Quackenbush, "Spatial wildlife vehicle collision models: a review of current work and its application to transportation mitigation projects, "J EnvironManag, 92:1074-1082, 2011.

http://dx.doi.org/10.1016/j.jenvman.2010.11.027

[5] C. Seo, H. J. Thorne, "Disentangling roadkill: the influence of landscape and season on cumulative vertebrate mortality in South Korea," Landscape Ecol Eng, 2015.

http://dx.doi.org/10.1007/s11355-013-0239-2

[6] ESRI, 2010 ArcGIS desktop: release 9.3.1. Environmental Systems Research Institute.

[7] O. Kim, H. An, J. Song, and J. Lee, "The roadkill Damage of Wild animal by fragmentation of Habitat in Gyeongsangnam-do province," J. Agric. Tech. Re. Inst, 14:97-110, 2001.

[8] S. Lee and H. Cho, "A Study of Wildlife Roadkill in Joongang Highway," Journal of environmental impact assessment, V.13 21-31, 2004. 